\title{
Cave morphology provides evidence of polyphase tectonics - an example from the Isverna karst system, South Carpathians
}

\author{
Laura Tîrlă \\ Faculty of Geography \\ University of Bucharest \\ Bucharest, Romania \\ tirla@geo.unibuc.ro
}

\author{
Virgil Drăguşin, Marius Vlaicu, Ionuț Mirea \\ Emil Racoviță Institute of Speleology \\ Romanian Academy \\ Bucharest, Romania
}

\author{
Daniela Dimofte, Relu-Dumitru Roban \\ Faculty of Geology and Geophysics \\ University of Bucharest \\ Bucharest, Romania
}

\begin{abstract}
Passage morphology and well-preserved kinematic indicators in a limestone-mélange contact cave from the South Carpathians provide evidence of thrusting mechanisms that occurred during the Late Cretaceous nappe emplacement. Large-scale normal faults occurred during the Eocene to Oligocene orogen-parallel extension, were deformed during the Late Miocene dextral strike-slip movements, which shaped a typical Riedel geometry across the Isverna area. Comparative orientation analysis of structural and geomorphological features indicates that karstification processes were directed along the NE-SWoriented normal faults, subsequently dissected by NW-SEoriented R'-shears. Where conditions were favorable, minor synthetic P-fractures inherited the normal fault planes. This study outlines the role of karst and caves in general and contact caves in particular in providing information on the mechanisms that controlled the polyphase tectonic evolution of an orogen area.
\end{abstract}

Keywords- karst; contact cave; thrust fault; structural analysis; Riedel fractures; tectonic geomorphology; South Carpathians

\section{INTRODUCTION}

Well-developed cave systems in the European orogenic wedges are related to the limestone-siliciclastite contact karst. This lithologic context is frequently linked to thinskinned thrust tectonics, commonly found in the accretionary wedges of the European alpine orogens [1]. The aquifers consist in porous limestone juxtaposed on clayey or clay-matrix formations of very low permeability.

Cave geometry in a karst system can be correlated with local and regional fault mechanisms. Caves may provide useful and novel evidences on the small- to large-scale tectonics, otherwise inaccessible from the surface, e.g. [2] and references therein. Conversely, tectonic facets such as fault sides or décollements (i.e., a type of thrust fault) which provided the path for cave-forming processes are able to provide new insights on speleogenesis. A particular geological setting for cave development can be found in the SW South Carpathians, where the Danubian and Severin nappes complexes are exposed. Ascunsă Cave [3] developed on the Cerna Nappe décollement and preserves structural, mineralogical, and geomorphic records of the deformation mechanisms.

We present here new evidences on thin-skinned thrust tectonics inferred from speleomorphology of the Ascunsă Cave, part of the active Isverna karst system (Mehedinți Mountains). Cave morphology and microtectonic records provided original information on the kinematic mechanism of the Cerna Nappe during its emplacement. Comparative analysis of joints, fractures, faults and cave passages revealed structural and geomorphic relationships that recorded the polyphase tectonic activity of the SW Carpathians. We demonstrate the way in which the development of karst conduits and interconnected surface landforms was directed along the normal faults and the Riedel shears that intersect across the Isverna hydrostructure.

\section{Lithologic AND STRUCTURAL SETTING}

The Isverna karst system is located in Mehedinti Mountains (SW South Carpathians), at elevations between $400 \mathrm{~m}$ and $1200 \mathrm{~m}$. It has developed into the uppermost cover nappe outcropping in the Danubian window - the Cerna Nappe. Its litho-stratigraphic units are: (a) 150-200 m-thick Urgonian limestones at the base, of BarremianAptian age; (2) Cenomanian-Middle Turonian thin-bedded marls and sandstones (Nadanova Beds); and (3) Upper Turonian-Maastrichtian tectonic mélange (s.l.) at the top. It overthrusts the Coșuștea Nappe, comprising siliciclastic sequences and mélange [4]. The latter consist in chaotically disposed 'blocks-in-matrix'-type fabric (or bim 
rocks), involving tectonic, sedimentary and gravitational forming processes [5]. The Urgonian limestones are karstified, all the conduits joining to a single common resurgence: Isverna Cave, at $450 \mathrm{~m}$ a.s.l. [6]. Ascunsă Cave is located at $1080 \mathrm{~m}$ a.s.l., where a small creek has deepened into the overthrust limestone and reached the underlying mélange. The cave entrance is located at the limestone-mélange contact. The rich aquifer facilitates water infiltration and organized flow along an extensive system of joints, fractures, bedding planes and solution cavities [7].

The Isverna hydro-structure is entirely comprised between the Obârșia Cloșani-Brebina (N) and IsvernaPonoarele (S) dextral strike-slip faults, hereafter referred to as the OCB and IP faults, respectively. They meet the NESW-oriented Cerna-Jiu fault system to the west.

\section{METHODOLOGY}

Structural analysis relied on examining the sense of shear and a comparative orientation study. Two types of Riedel shears were used: the microshears visible on the cave walls related to limestone sheet overthrust movement, and the fracture sets developed across the Isverna hydrostructure.

Cave survey and geomorphological mapping of the surface karst were used to obtain the structural data - faults and fractures $(\mathrm{n}=186)$ from an area of about $38 \mathrm{~km}^{2}$. We analyzed the type of faults and Riedel fractures according to their orientations and position with respect to principal displacements: the orogen-parallel normal faults, the major synthetic R and antithetic R' shears, and the minor synthetic P-fractures. For the strike-slip system, the direction of the maximum compressive stress $\left(\sigma_{1}\right)$ was inferred from fracture geometry, according to Anderson's theory of faulting.

Comparative orientation analysis between the fault and fracture system and the segments of Ascunsă and Isverna caves (38 and 123 segments, respectively) was combined with microtectonic measurements on randomly distributed joint sets across the entire Isverna hydro-structure $(n=759$ joints). Orientations were plotted on rose diagrams as nonpolar frequency lines organized into 10-degree bins. We performed the survey of Ascunsă Cave using a Leica Disto X310 laser range finder fitted with electronic compass and clinometer. We focused on the passage morphometry and its relationship to the thrust fault and the strike-slip shear system. Cave and surface karst survey was followed by data integration into a GIS environment.

\section{RESULTS}

\section{A. Structural mineral fabrics as kinematic indicators}

The 1-5 mm-thin laminae of the argillaceous matrix are oriented parallel to the limestone ceiling and exposed throughout the sides of the main passage. Where present, microshears display a Riedel-type arrangement indicating the sense of shear towards WNW.

A giant slickenside forms the cave ceiling at $\sim 25 \mathrm{~m}$ from the entrance. Well-preserved mineral and mechanical lineations were found both on the ceiling and the opposite

This study was financially supported by the IFA-CEA C4-08 (FREem) project slickensides consisting in detached limestone slabs. Position of the calcite slickenfibers is $292 / 25$, showing the direction of movement of the limestone edge over the mélange, which is also towards WNW.

\section{B. Evidence from speleomorphology}

Cave passages consist in alternating large chambers (up to $20 \mathrm{~m}$ in width and $10 \mathrm{~m}$ in height in the Great Chamber) and very narrow phreatic tubes $(\sim 0.5 \mathrm{~m}$ in width), with interposed passages of small to intermediate size (2-3 $\mathrm{m}$ in width and height). The cave currently reaches the maximum depth of $-132.2 \mathrm{~m}$, with further exploration possibilities.

The chambers have a planar ceiling dipping under various angles $\left(25^{\circ}-55^{\circ}\right)$, an indicator for the typical ramps-and-flats morphology of thrust faults. The ceiling is well-decorated with stalactites and locally with shields. Many types of speleothems cover the uneven floor, having a chaotic arrangement. Phreatic tubes were carved mostly or entirely into the overlying limestone beds and walls preserve different-sized scallops, small cupolas formed by evorsion and ceiling channels. The longitudinal profile of the Ascunsă Cave shows the current dip of the deformed décollement. The general fault dip inferred from the cave dip ranges between $20^{\circ}-25^{\circ}$, with the steep breaks formed both into the ceiling and the floor indicating the dropped blocks of the overlying limestone bedrock.

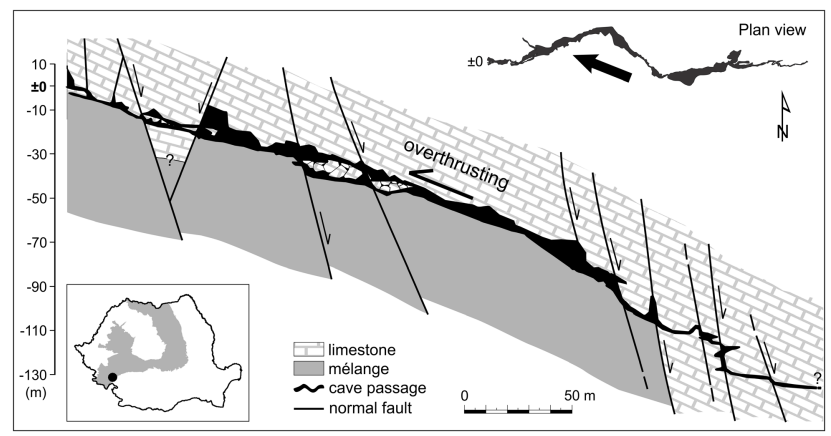

Fig. 1 Longitudinal profile of the Ascunsă Cave, adapted to typical ramps-and-flats structure of the thrust fault. The direction of movement of the limestone sheet during the Late Cretaceous nappe emplacement is shown by the black arrow in the plan view. The normal fault system is much younger and related to Early Tertiary orogen-parallel extension.

\section{Orientation analysis of joint sets, faults, fractures and cave passages}

Manually-extracted fractures from the strike-slip shear zone form the characteristic Riedel sets (Fig. 2). Preferred orientations are: E-W for the major strike-slip faults and minor parallel Y-fractures; ESE-WNW for the major synthetic R shears; NW-SE for the major antithetic R' shears; ENE-WSW for the minor synthetic P-fractures; and NNE-SSW for the deformed R' shears. However, we identified numerous short fractures striking on a NE-SW direction, which is not typical of a Riedel arrangement. Their probable origin will be discussed below.

Joint orientations differ considerably from the situation described above. Most joints $(n=235)$ are $\mathrm{W}$-E-oriented, corresponding to the major strike-slip movement. Another four preferred orientations are still noticeable: N-S, NE- 
SW, ENE-WSW and WNW-ESE. All of them have comparable samples in size (50-65 joints) and correspond to synthetic and antithetic fracture systems.

There is a high correlation between the fracture and cave passage orientations, which fall into two general directions: NW-SE and NE-SW (to ENE-WSW). Ascunsă Cave developed mostly along the ENE-WSW-oriented fractures (347 m, namely 75\% of its total length, which is $691.5 \mathrm{~m}$ [3]) and less along the NW-SE (103 m, meaning $15 \%$ of its length). In case of Isverna Cave, NE-SWoriented passages account for $1.91 \mathrm{~km}$ (50\%), W-Eoriented segments cumulate $1 \mathrm{~km}(25 \%)$, and those NWSE-oriented account for $0.68 \mathrm{~km}(17 \%)$. Its total measured length reaches $\sim 3.9 \mathrm{~km}[6]$.

Geomorphic relationships between the cave system and the exokarst were also driven by the structural network. Tens of sinkholes can be found on the less inclined surfaces of the limestone bedrock, spatially distributed along the $\mathrm{R}$ ' and $\mathrm{P}$ fractures. Their diameter ranges between 20-50 m, rarely exceeding $150 \mathrm{~m}$, and depths between 5-10 m.

\section{DISCUSSION}

The cave formed by removal of the argillaceous matrix through underground flow in an unconfined aquifer. Differential response of the limestone and bim rocks to water action under both phreatic and vadose conditions has resulted in extremely narrow or low passages alternating with large chambers. Formation of the great chambers was primarily controlled by the fault and fracture intersections. The narrow tubes correspond to minor tensile fractures developed into the dropped limestone hangingwalls. Scallops, cupolas and ceiling channels are typical evidence of an earlier phreatic flow phase. The cave continuously deepens along the ramps-and-flats contact between the mélange and the limestone cover.

The WNW-trending calcite slickenfibers preserved inside the cave $\left(292 / 25^{\circ}\right)$ certainly indicate the sense of displacement of the Cerna Nappe. This assumption is strengthened by the shear sense analysis of the Riedel microshears developed at the limestone-mélange contact.

Fault and fracture geometry indicates a structural arrangement typical to a dextral strike-slip shear zone [8], comprised between the OCB and the IP faults. Joint orientations reflect the general displacement trend of the strike-slip zone, corresponding to a W-E direction. Cave passages and surface karst landforms developed mainly along two preferred orientations: NE-SW, and NW-SE. These would normally correspond to R' shears and Pfractures, only that the latter are usually minor fractures unable to direct karstification at such scale without an extra-backing. The structural support seems to have been provided by an earlier fault system that pre-dates the strike-slip movements. Field and orientation analysis of several presumable P-fractures indicated that these took over the remnants of some older normal faults, intersected and displaced by the younger R' shears. Reconstruction of these large-scale faults (Fig. 2) shows their parallelism with the Cerna-Jiu master fault, striking NE-SW and located northwestward from the study area.

At Isverna Cave, located near the IP Fault, the synthetic $\mathrm{R}$ and conjugate $\mathrm{R}$ ' shears controlled the development of southern passages. Towards north, passages developed within the innermost displacement zone were directed mainly along the deformed normal faults and P-fractures.

We inferred the type of faults and fractures mainly from karst geomorphology in relation to the polyphase tectonic evolution of the South Carpathians, as follows:

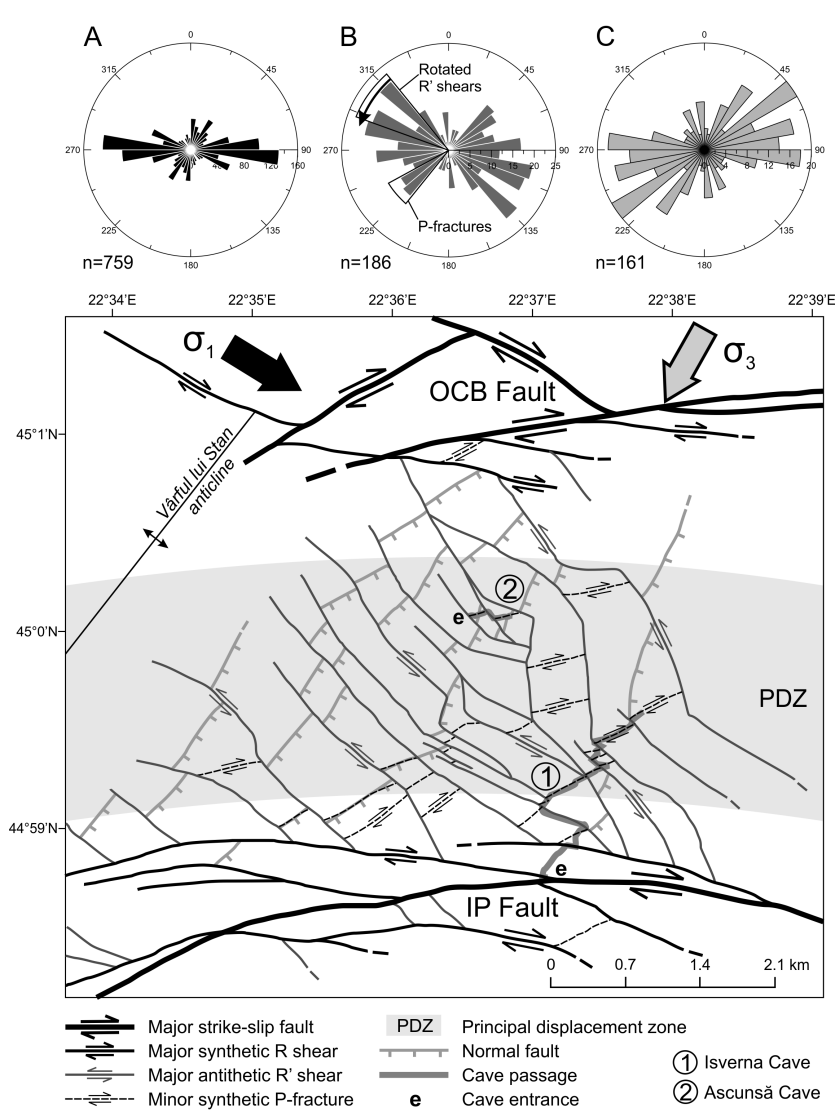

Fig. 2. Strike-slip tectonics and cave development in the Mehedinți Mts, showing comparative orientations for joints (A), faults and fractures (B) and cave passages (C). Isverna Cave survey data provided by Z. Gyurka, 2000 (unpublished material)

- The limestone bedrock forms the basal layer of the Cerna Nappe, emplaced during the Intra-Senonian tectogenesis (Late Cretaceous) by overthrusting the argillaceous ductile matrix of the Coșuștea Nappe mélange. Ascunsă Cave is a typical contact cave developed along the décollement.

- Eocene-Oligocene orogen-parallel extension produced large-scale normal faults in the South Carpathians. A number of faults parallel to Cerna fault cut across the Isverna hydro-structure. Tilted block faulting is not excluded. Numerous karst landforms formed along these segmented faults: sinkholes, potholes, karst valleys, and caves.

The Late Miocene tectonic phase determined the formation of W-E-oriented transcurrent faults and the related Riedel arrays and splays [9], preparing the framework for valley development and cave inception. Geomorphic diversity is particularly rich within a band comprised between the OCB and the IP faults, called the principal displacement zone (PDZ). The zig-zag pattern of the internal damage zone occurred at a later stage of the shear-zone evolution [10]. The direction of the principal 
compressive stress record $\left(\sigma_{1}\right)$ is WNW-ESE, and has changed over time due to the rotational character of the strike-slip movement. The principal minimum stress $\left(\sigma_{3}\right)$ is tensile and perpendicular on $\sigma_{1}$ (Fig. 2), and the intermediate stress $\left(\sigma_{2}\right)$ is vertical.

\section{CONCLUSIONS}

This study presents new data on the speleomorphology and development of interconnected underground conduits in the contact karst from the South Carpathians under specific lithotectonic settings.

At Ascunsă Cave, walls and ceiling provided mineralogical, mechanical and morphological evidence of the tectonic activity during the nappe emplacement and the post-dating extensional regime. Calcite slickenfibers grown on limestone slickensides and Riedel microshears show that the direction of the nappe movement was ESEWNW. The chambers formed at shear intersections mainly by mélange removal and underground collapses, whereas the narrow passages were incepted and developed along subsidiary fractures under phreatic conditions. These tubes are morphological indicators for normal faulting, as they developed only inside the dropped limestone hangingwalls.

Development of the Isverna karst system is under the primary control of the Obârșia Cloșani-Brebina and Isverna-Ponoarele dextral strike-slip faults, on the one hand, and the NE-SW-oriented normal faults related to a pre-dating orogen-parallel extension, on the other. The Riedel shears are pathways for water infiltration from the epikarst zone and organized flow at greater depths. Karst conduits developed along the R'-shears and normal faults, striking NW-SE and NE-SW to ENE-WSW, respectively. The P-fractures partly inherited the normal fault system, highly dissected and deformed by the subsequent strikeslip movements. Quaternary mountain uplift may have reactivated them. In parallel, surface karst landforms follow the same orientation pattern, having been developed along the segmented normal faults and major antithetic R' shears.

This study conducted towards a better understanding of the tectonic control exerted by the Late Cretaceous thin-skinned thrusting, orogen-parallel extension and subsequent Miocene to Quaternary deformations, acting as drivers of the karstification processes in the SW South Carpathians. We also outlined the role of contact caves in providing more evidence on fault kinematics than any other surface landforms or outcrops in mid-latitude environments.

\section{ACKNOWLEDGMENT}

We are grateful to $\mathrm{C}$. Dinu for improving remarks regarding tectonic mechanisms. We kindly thank E. Isverceanu and his family for their permanent support during the field work.

\section{REFERENCES}

[1] T. McCann, The Geology of Central Europe: Mesozoic and Cenozoic. London: Geological Society of London, 2008

[2] S. Shanov and K. Kostov, Dynamic Tectonics and Karst. Berlin Heidelberg: Springer-Verlag, 2015

[3] V. Drăgușin, M. Vlaicu, and E. Isverceanu, "Mehedinți Mountains The Cave from Mohilii Creek", in Caves and Karst Systems of Romania, B. P. Onac and G. Ponta, Eds. Berlin: Springer (in press)

[4] A. Seghedi and G. Oaie, "Sedimentology and petrography of sandstones in cover nappes in the central South Carpathians: constraints for geotectonic setting”, in Geology of the Djerdap area. International Symposium Geology, A. Grubic and T. Berza, Eds. Orșova, 1997, pp. 277-279.

[5] A. Festa, G. A. Pini, Y. Dilek, and G. Codegone, "Mélanges and mélange-forming processes: a historical overview and new concepts”, International Geology Review, vol. 52, no. 1, pp. 10-12, 2010.

[6] M. Baciu, G. Mogyorosi, V. Drăgușin, Z. Gyurka and S Storozynski, "Mehedinți Mountains: Isverna Cave", in Caves and Karst Systems of Romania, B. P. Onac and G. Ponta, Eds. Berlin: Springer (in press)

[7] G. Ponta, "Geology and dynamics of underground waters in Cerna Valley/Băile Herculane (Romania)", Carbonates and Evaporites, vol. 28, no. 1, pp. 31-39, 2013.

[8] H. Fossen, Structural Geology. Cambridge: Cambridge University Press, 2010.

[9] L. Mațenco and S. Schmid, "Exhumation of the Danubian nappes system (South Carpathians) during the Early Tertiary: inferences from kinematic and paleostress analysis at the Getic/Danubian nappes contact”, Tectonophysics, vol. 314, pp. 401-422, 1999.

[10] Y. Katz, R. Weinberger and A. Aydin. "Geometry and kinematic evolution of Riedel shear structures, Capitol Reef National Park, Utah”, J Structural Geol, vol. 26, pp. 491-501, 2004. 